\title{
AN OVERVIEW OF RESEARCH ON GENDER IN SPANISH SOCIETY
}

\author{
CELIA VALIENTE \\ Universidad Carlos III de Madrid, Spain
}

This article presents an overview of research on gender in Spanish society. Six areas of literature are examined including families, education, work, politics, sexuality, and men. The author argues that political factors have shaped the development of sociology of gender in Spain and that there are still important gaps in coverage in this area of sociological inquiry.

This article offers an overview of research on gender in Spain. The aims of this report are to describe the existing state of research, to identify the gaps in coverage, and to supply a bibliography of existing research. A main argument in this article is that the development of sociological studies on gender in Spain has been influenced more by the political evolution of the country than by the social transformation of Spanish society.

At least three factors explain the significant impact of political factors on scholarship on gender and society. First, from the mid-1930s to 1975, Spain was governed by a right-wing authoritarian regime headed by Franco that actively opposed the advancement of women's rights and status. Therefore, prior to the 1970s, very few analyses were carried out on gender and society. Second, many specialists on gender have been members of or sympathizers with the Spanish feminist movement. Thus, the topics of interest for researchers and the activist interests of participants in the movement have largely coincided. Comparatively speaking, Marxist feminism has been central in the Spanish feminist movement while the liberal and radical groups have been less important (although not negligible). Therefore, priority issues for Marxist feminists, such as women's work, have been more intensively

AUTHOR'S NOTE: I would like to thank Kerman Calvo and Gracia Trujillo for their bibliographical advice and valuable comments on parts of an earlier draft. The staff of the library of the Women's Institute (Centro de Documentación del Instituto de la Mujer) provided me with valuable help in the search of sources for this article.

REPRINT REQUESTS: Celia Valiente, Department of Political Science and Sociology, Universidad Carlos III de Madrid, Calle Madrid 126, 28903 Getafe; e-mail: Valiente@polsoc.uc3m.es. 
studied than other topics, such as sexuality, which is a central concern for radical feminists. However, this article makes a conscious effort to present not only Marxist analysis but also other studies undertaken from different theoretical and empirical perspectives. Third, most of the financial support for research on gender and society comes directly or indirectly from the state. Especially since the 1990s, gender researchers have been increasingly busy writing reports for policy makers. Public authorities have thus been able to privilege their preferences and influence the field of gender analysis.

This short article is not exhaustive but rather provides a general picture of the state of sociological research on gender in Spain. I have selected works using three primary criteria. First, the works discussed here typically use gender as the main dimension in the analysis of the Spanish society in the democratic period (19752001). Works that deal with other topics, but use gender as one of many variables, are not included here because this type of research remains very rare in Spain. Second, only published works are included. Third, all of the publications are based on empirical research.'

Scholarship on gender in Spanish society differs from research on gender and society undertaken in the United States in at least six ways. As I describe below, most Spanish works (1) are macrosociological and descriptive, (2) are not comparative, (3) lack sophisticated quantitative analysis, (4) lack a systematic international perspective, (5) do not follow the American style of publication, and (6) do not have to pass severe quality filters in order to be published.

A significant proportion of studies on gender in Spanish society are macrosociological; these analyze the whole society or (more often) social institutions such as education or the economy. Very few works examine small groups where face-to-face interactions take place (such as peer groups) or individual behavior (e.g., cognitive processes). Therefore, most works commented on in this review are descriptive and limited to the documentation of the subordinate position of women in society. There are few explanatory works that analyze why and how women have unequal access to economic rewards, decision-making power, and social prestige. The majority of the studies examined are not comparative, as there is no tradition in Spain of doing comparative studies in social sciences (Uriarte 1997a, 27). Even quantitative research pieces on gender and society are usually descriptive reports (e.g., of the number of women enrolled in university education) and rarely use more complex statistical techniques such as regressions.

With relevant exceptions, most research cited in this article does not refer to international studies, discussions, and/or debates. When Spanish scholars make reference to international works, they usually do so to support their hypotheses. Spanish researchers rarely attempt to contribute to international debates and discussions. This is the case not only with research on gender but with all research in the social sciences.

I can offer some explanations for the lack of international perspective that characterizes the production of scientific knowledge. Most Spanish scholars do not master foreign languages, because these are not well taught at school. The over- 
whelming majority of research is published in Spanish and written by authors with the Spanish audience in mind. Generally speaking, there is not a premium in the university system for those researchers who work in international projects or publish abroad; this is especially true at the beginning of one's academic career. ${ }^{2}$ The authoritarian regime severely limited the contacts of intellectuals and social scientists with foreign colleagues. The authoritarian government also prohibited the circulation of many international publications.

The Spanish style of publication differs from the typical U.S. pattern for a social science research article in which introduction/theory/data and methods/analysis/ conclusion sections are systematically followed by most authors. Spanish pieces may lack one or more of these sections. In general, works do not have to pass strict quality tests to be published in Spain. Although the system of blind peer review is spreading among journals and book publishing houses, it is not yet the norm. In Spain, authors' connections are often as important as (or more important than) the quality of research in decisions regarding publications in the social sciences. Therefore, it is not surprising that Spanish journals generally are not included in international social sciences citation indexes. The lack of prevalent rigorous review procedures does not mean the absence of high-quality works. Some studies are excellent, but the overall quality level of publications in Spain is significantly lower than in other countries where blind peer review is firmly established.

It is important to note that in Spain, researchers on gender and society have been (and currently are) facing at least one serious difficulty while conducting research: the very negative image that gender issues have among most scholars. In Spain, people who do gender studies are usually women, and they are viewed as feminists. This is a practical obstacle for the development of research on gender and society because being a feminist is regarded negatively by society and by the academic world (Uriarte 1997a, 17-18). Gender research is a risky option for scholars, who may be denigrated by others (whether openly or not). Many mainstream sociologists think that gender is a much less important topic for study than other classical sociological issues such as socioeconomic status. Thus, it is understandable that very few Spanish scholars openly define themselves as feminist researchers. Consequently, it is often very difficult to determine which works are feminist and which are not. In this article, I have decided to review works in which the authors do not overtly or implicitly deny that women as a group occupy a subordinate position in society in comparison with men and that this subordination should be reversed. Therefore, I have included studies that in other countries would not be considered feminist. Most Spanish sociologists specializing in gender are interested in both describing and denouncing gender inequality, as is the case with most research about gender issues in Spain (Alberdi and García de León 1990). There is an elision in some pieces between scientific analysis and normative concerns (Uriarte 1997a, 15).

In spite of several difficulties, scholars have been able to develop what now constitutes an ample body of academic work on gender in Spanish society. It is to this review of the literature that I now turn. I divide the works on gender and society into six sections or topics: families, education, work, politics, sexuality, and men. ${ }^{3}$ 


\section{FAMILIES}

In general terms, (mainstream) sociology of the family is an underdeveloped subfield of sociology in Spain, although this situation has been changing slightly since the 1990s (Iglesias de Ussel and Flaquer 1993, 69; Meil Landwerlin 1998, 179-80). Gender scholars have paid less attention to the study of families than to the study of other dimensions of social life, such as education or work. The relative shortage of feminist studies on families may be explained by historical factors. The earlier authoritarian political regime prescribed that women's principal role in society was full-time dedication to their families. The last goal that feminist scholars wanted to accomplish after the dictatorship was to focus their intellectual energies on the analysis of the social institution so dear to Francoist official discourse and propaganda.

However, scholars have studied decision-making processes and the division of labor within families. Regarding decision making, dramatic changes have taken place in most Spanish families in the past three decades. Family life is currently based much less on wives' and children's obedience to husbands/fathers and more on dialogue and negotiation between family members. In contrast, equally important transformations have not happened in the gender division of labor within families. In Spain, large percentages of both sexes believe that household and caring tasks should be shared between both members of the couple. However, in practice, the main (or sole) family responsibility of many men is to serve as the breadwinner, while women (whether workers or homemakers) take responsibility for most domestic and care work. Thus, the combination of professional and family responsibilities is an acute problem for many Spanish women of working age (Alberdi 1995, 1999; Álvaro Page 1996a, 1996b; Carrasco 1991; Finkel Morgenstern 1997; INNER 1988; Izquierdo, del Río, and Rodríguez 1988; Ramos Palomo 1998; Ramos Torres 1990; Tobío Soler 1999).

Scholars have developed a particular interest in what does not work in family life or in what is not the typical nuclear family. As a result, we can now rely on works about divorce (established in Spain only in 1981) (Alberdi 1979; Domenech Almendros 1994; González Duro 1999; Hernández Rodríguez 1996), domestic violence (and violence against women in general) (Fagoaga 1994; Maquieira d'Angelo and Sánchez Muñoz 1990; Martín Serrano and Martín Serrano 1999; Ministerio del Interior and Instituto de la Mujer 1991; Osborne 2001; Rodríguez, Álvarez, and Gómez 1988; Roig 1994; Rubí Pato and Núñez González 1994; Servicio Galego de Promoción da Igualdade do Home e da Muller 1992; Younis 1999), and families headed by an adult (usually a woman) (Alberdi and Escario 1986, 1990; Arbiza Berregui 1978; Fernández Cordón and Tobío Soler 1998, 1999; Iglesias de Ussel 1988; Madruga and Mota 2000; Moreno 2000; Tobío Soler and Fernández Cordón 1999). However, scholars' engagement by what used to be called atypical family phenomena is limited. Many of these issues are rarely studied, including families formed by people of the same sex. 
We know very little if anything about many aspects of family life. Let me illustrate this point with two examples. The field of feelings, emotions, love, and intimacy is almost an unexplored territory. This is paradoxical, given that the family is usually conceived of as the private and intimate realm. Also unknown is the experience of girls within families. We know very little about this matter, apart from some basic facts such as that girls perform more domestic tasks than boys. ${ }^{4}$

\section{EDUCATION}

Education is one of the gender areas in which substantial research from a gender perspective has been undertaken in Spain. As in other countries, historically, girls were enrolled in the education system in considerably lower proportions than boys. Girls and boys usually attended sex-segregated schools and were taught a different curriculum. In contrast to the boys' curriculum, the girls' curriculum included a strong component of domestic skills (mainly sewing) and religious (Catholic) activities (chiefly prayers). ${ }^{5}$ Girls' curriculum contained fewer academic subjects than did boys' curriculum. The quality of training for teachers who worked in girls' schools was lower than that of teachers in boys' schools. Since the nineteenth century, and especially during the democratic regime of the Second Republic (19311936), some experiments with mixed schools took place. However, mixed schooling was forbidden by Francoist authorities in 1939, and sex-segregated schools became again the norm. It was only in 1970 that mixed schools were permitted again and in the mid-1980s that these became the established pattern. Today, only a tiny minority of schools are sex segregated in Spain (Ballarín Domingo 1994; Capel Martínez 1986; Cortada Andreu 1988).

Because sex-segregated schools have been associated with the authoritarian period and backwardness, the overwhelming majority of social scientists, policy makers, and social actors have favored mixed schools. Therefore, in contrast with Anglo-Saxon countries, in democratic Spain, no debate has emerged on the potential usefulness of sex-segregated schools for girls. While supporting mixed schools, social scientists have studied practices in these schools that hinder girls and women (Arenas Fernández 1996; Campo Bolado et al. 1996; Izarra and López Carretero 1999). Researchers have identified at least seven areas where sexist practices exist: textbooks, curriculum, teachers' actions in the classroom, interaction among students, students' academic options, the feminization of the teaching profession, and pupils' positions in the labor market after the completion of their studies.

First, textbooks provide gender-biased views of social reality. For instance, women are mentioned and represented in textbooks much less frequently than men are. Textbooks tend to ignore women's experiences and privilege men's activities (Blanco García 2000; García, Troiano, and Zaldívar 1993; Garreta and Careaga 1987; Moreno 1992). Second, since the 1970s, the extension of mixed schooling took place by using the former boys' curriculum to teach pupils of both sexes rather 
than by integrating the former boys' and girls' curricula. As a result, women's traditional skills were given less importance (or no importance at all) than men's (Alberdi and Alberdi 1984; Fernández Enguita 1991). Third, teachers (often unconsciously) interact more often with male than with female pupils, hold hostile opinions of girls, have different (and higher) expectations for the professional careers of boys than of girls, and use masculine language forms (for example "boys" or "men") when referring to female and male pupils or, even worse, when referring only to female students (Arenas Fernández 1996; Calero Fernández 1999; Instituto de la Mujer 1987b; Subirats and Brullet 1988). Fourth, students' own behavior contributes to gender differentiation in school. For example, male students (especially older ones) tend to use more space in the schoolyard because they play space-consuming sports such as soccer and basketball, while girls are relegated to the sides and corners of the playground (Bonal 1998). Fifth, students tend to choose different courses depending on their sex, following the common pattern existing in other countries. In spite of the fact that on average, girls' academic performance in primary and secondary education is as good as (or even slightly better than) that of boys, girls tend to be overcrowded in studies of humanities and social sciences, while boys are in technical and scientific studies (Álvarez et al. 1970; De Borja 1970). Sixth, the teaching profession was male up until the nineteenth century, when it started to become a female profession through a process of losing prestige and pay (San Román 1998). Finally, as in the United States, the same level of education improves women's opportunities in the labor market less than it improves men's opportunities (Casal, Masjuan, and Planas 1989).

As for the Spanish university system, among other topics scholars have studied is why men outnumber women in teaching or research and administrative positions, while the numbers of female and male university students are approximately the same in the university as a whole. These researchers have focused on a number of factors including sex-biased informal practices of hiring and promoting and the difficulties of combining professional and family duties (Almarcha Barbado, González Rodríguez, and González Jorge 1994; Carreño et al. 1998; Fernández Villanueva 1989; García de Cortázar and García de León 1997; Sanz Rueda 1995).

In sum, studies on gender and education in Spain have provided us with a nuanced picture of school sexism, which is "invisible, unconscious, and subtle" (Bonal 1997, 23). However, Spanish researchers have developed a taste for the study of indirect sexism and have neglected the analysis of more open and direct practices, such as violence against girls or sexual harassment. These more overt attacks also exist in the Spanish education system and merit scholarly attention. On the other hand, more research is needed on the egalitarian dimension of education. Some scholars have argued (Fernández Enguita 1989, 1990) that schools allow women to experiment with equality of treatment to a higher degree than other social arenas such as the labor market or the family. The impact of these comparatively higher doses of equality on girls' and women's lives are still underanalyzed. 


\section{WORK}

Work is the dimension of social life that has attracted the most scholarly attention by specialists in gender. In the 1960s and 1970s, the participation of women in the labor market in Spain was among the lowest in the Western world. Since then, women's employment rates in Spain have constantly increased. ${ }^{6}$ During the Francoist regime (especially up to the 1960s), the state established numerous policies against women's paid employment such as marriage bars, or prohibitions on entering certain professions, for instance, in the fields of medicine and law. Married women needed their husbands' permission to sign labor contracts and engage in trade. Not surprisingly, the second wave of the feminist movement has made the access to employment one of its most important (or perhaps the most important) demand. Spanish feminists have tirelessly argued that women must participate in the labor market to be liberated since the majority of the people of working age acquire economic autonomy only through paid employment. The centrality of work among the demands of the feminist movement reflects the influence of Marxism.

After the dictatorship, as women were entering the Spanish labor market in increasingly higher numbers, scholars documented phenomena that had already been observed in other countries. In spite of the equality before the law achieved with democracy, on average, women's wages and salaries are lower than men's. Women are underrepresented among people who occupy decision-making positions in companies and among employers. Women are overrepresented among workers with temporary contracts, workers with shorter working records, part-time workers, workers employed in the underground economy, workers who work at home, and unemployed individuals. Women are overcrowded in some jobs and professions, while men perform a wider range of jobs and professions.

To explain women's subordinate position in the Spanish labor market, researchers have elaborated two types of explanations: supply-side and demand-side arguments. Supply-side accounts argue that women and men are different kinds of employees when they offer their working potential to employers. For instance, women have different educational backgrounds than men or have more domestic and caring responsibilities at home. As a result of these and other differences, women's and men's prospects in the labor market are dissimilar. Researchers using this supply-side perspective have mainly analyzed the aforementioned differences between women and men. In contrast, demand-side analysts propose that women and men are treated differently in the labor market. Women are discriminated against, and discrimination is the main factor that explains the unequal position of female and male workers. Scholars using this perspective have chiefly studied gender discrimination. However, some forms of discrimination (e.g., that concerning wages and salaries) have been more extensively researched than others (such as sexual harassment at work) (Alcobendas Tirado 1983; Benería 1977; Borderías Mondéjar 1986; Calle Fuentes, González Romero, and Núñez Triguero 1988; Castaño et al. 1999; Cousins 1994; De la Fuente Vázquez 1998; Escario and 
Alberdi 1987; Fernández Méndez de Andrés et al. 1987; García Ferrando 1977; García Ramón et al. 1995; Instituto de la Mujer 1987a, 1989, 1997; Lázaro and Sánchez 1993; Liceras and Murillo de la Vega 1992; Martín Urriza and Zarapuz Puertas 2000; Moltó Carbonell 1993; Moreno Raymundo, Rodríguez Rodríguez, and Vera Grijalba 1996; Peinado López 1988; Pernas et al. 2000; Romero López 1987, 1990; Ruesga 1991; Sáez Lara 1994; Sallé and Casas 1987; Sanchís 1984; Torns, Borràs, and Romero 1999; Valenzuela Ratia 1979).

Spanish feminist scholars have insisted that prevailing notions of work reflect male experiences of participation in the labor market in exchange for wages and salaries. Women perform enormous amounts of work that are not considered as such because they are nonpaid. The nonwaged domestic and care work performed by a high proportion of Spanish homemakers (and by employed women doing their second shift) has then been analyzed. Some scholars have also tried to quantify nonwaged women's work and include it into the calculation of national accounting data, such as the gross domestic product (Carrasco 1991; Durán 1987).

Spain has traditionally been a country that exported its people as migrants to other countries, but it is now in the reverse situation. The appearance of a new social phenomenon (the arrival of immigrants, many of whom are women) has caught the attention of feminist researchers (Gregorio Gil 1998; Maquieira d'Angelo, Gregorio Gil, and Gutiérrez Lima 2000). Finally, the Spanish welfare state has also been studied from a gender perspective. The Spanish welfare state is of a continental type, according to the typology elaborated by Esping-Andersen (1990). In this type of welfare state, social rights are linked to occupational categories and status (e.g., there are different insurance schemes for different types of workers). Since women's experience in the labor market is less than that of men, the Spanish welfare state tends to overbenefit male citizens (Carrasco et al. 1997; Cousins 1995; Guillén 1997; Valiente 1997a).

\section{POLITICS}

Three topics on politics in Spain have caught the attention of most gender researchers: women as conventional political actors (mainly as voters, candidates, and officeholders), women as nonconventional political actors (chiefly as participants in the women's movement), and gender-equality policies.

Studies on women as voters (García Escribano and Frutos Balibrea 1999; Morales 1999; Threlfall 1979; Uriarte 1997c) have documented that in the first democratic elections in Spain, higher proportions of women than men preferred conservative political options. This difference between the voting patterns of men and women has been eroded ever since. The almost complete disappearance of gender differences regarding voting in Spain contrasts with other countries such as the United States where the expression "the gender gap" describes a tendency for women to vote for more liberal political options than men since the 1980s. Scholars specializing in gender in Spain have studied other gender dissimilarities in con- 
ventional political participation such as membership in political parties and trade unions (Astelarra 1990; Instituto IDES 1988; Ortiz Corulla 1987).

Women's presence in conventional political positions (members of the Council of Ministers, Parliament, the senior grades of the administration, and leaders of political parties) has risen throughout the whole democratic period. For instance, in the lower chamber of Parliament (Congress of Deputies), the proportion of female members of Parliament has increased from 6 percent in the first democratic parliamentary term (1977-1979) to 28 percent in the current term. In this regard, Spain occupies an intermediate position among European Union member states and is far ahead of the United States (14 percent). The proportion of women among members of the upper chamber (Senate) in Spain is 24 percent, while that proportion for the United States Senate is 13 percent (Interparliamentary Union 2001). Spanish studies have not only mapped the presence of women in conventional decision-making positions but also attempted to explain how and why women reach (or do not reach) these positions (Gaitán and Cáceres 1995; García de León 1991, 1996; Gutiérrez and Pastor 1996; IMOP Encuestas 1999; Instituto de la Mujer 1993a, 1993b; Molina Petit 1996; Uriarte 1997b, 1997c, 1999; Uriarte and Ruiz 1999). Several factors have been identified that hinder women's political recruitment and promotion, including the unwillingness of men to designate women for governing posts, the lack of role models, and the difficulties of combining political and family responsibilities.

With regard to women's nonconventional political mobilization, the feminist branch of the women's movement has been amply researched (Borreguero et al. 1986; Di Febo 1979; Durán and Gallego 1986; Escario, Alberdi, and LópezAccotto 1996; Fernández and Aierdi 1997; Folguera 1988; Grup de Feminisme de l'Escola de Sociologia de Barcelona 1978; Kaplan 1992; Pineda 1995; Puleo 1994, 1996; Salas 1996; Scanlon 1976; Sundman 1999; Threlfall 1985, 1996; Valiente 2001c). The political environment influenced the feminist movement regarding its political allies, its goals, its organizational structures, and its activities, among other dimensions. The second wave of feminist collective activism appeared around the 1960s and 1970s in opposition to the authoritarian regime, where it encountered mainly (illegal) left-wing political parties and trade unions. These have been the political allies of the feminist movement ever since. An important proportion of the goals of the feminist movement has been instrumental (as opposed to expressive). The feminist movement has also demanded the democratization of the country. The movement has been unable to establish strong and long-lasting umbrella organizations in part because of the close links of women's groups with parties. The interest in political reform and the close alliance with the Left gave feminists incentives to use conventional forms of collective action because these were the preferred forms of action for left-wing parties and trade unions (feminists' allies) to reach political aims. The fact that the state did not provide women with some services that they needed, such as sexual information, contraceptives, and legal advice, made Spanish feminists willing to invest considerable energy in service provision since the 1970s. Service provision by feminists has been further accentuated since the 1980s (to the 
detriment of identity-oriented activities), when the state started giving subsidies for women's organizations that provide services.

We know much less about the nonfeminist branch of the women's movement, which is formed by housewives' organizations, widows' associations, mothers' movements, and cultural and religious associations, among others (but see Oleaga 1990). Scholars specializing in gender in Spain tend to study the social movements (and in general the topics) that they like, and not those that they do not like, even if these may be very interesting from a sociological point of view. This selection of the object of study is regrettable because the majority of women who belong to women's organizations in civil society and mobilize through them are not members of feminist groups.

With respect to studies on gender equality policies at the central, regional, and local state levels (Arranz 2000; Astelarra 1994; Bustelo Ruesta 1999; Gil 1996; González and Almarcha 1993; Granados Vaquero 1999; Martínez and Elizondo 1997; Mendizábal and Ortiz 1996; Sampedro 1992; Sensat and Varela 1998; Threlfall 1998; Valiente 1995a, 1995b, 1996, 1997a, 1997b, 1997c, 1998, 19981999, 2001a, 2001b), we now know that the establishment of most of these policies has been promoted in Spain in the past three decades by women's policy agencies ${ }^{7}$ and/or feminists within political parties and trade unions rather than by the women's movement or by both, as in other countries. The literature has tended to study the policy-making process in relation to gender equality but has paid little attention to evaluating the effectiveness of those policies.

\section{SEXUALITY}

The sociology of sexuality is one of the topics of sociological inquiry that is least developed in Spain (Guasch 1993; Iglesias de Ussel 1983). Even fewer works on sexuality have been undertaken from a gender perspective. Some studies have described (and denounced) the rigid sexual mores imposed on women during the authoritarian period that allowed them to be sexually active only within marriage and exclusively while pursuing reproduction. Men's sexuality was also repressed, but to a considerably lesser degree. The liberalization period of the dictatorship and the subsequent democratization of the country were accompanied by a process of relaxation of sexual taboos and repression and a partial revision of the double moral standard, which was significantly looser for men than for women. However, we have only impressionistic accounts of these changes (Aranguren 1973; Castaño 1996; A. De Miguel 1975; J. De Miguel, 1979; López 1990; Serrano Vicéns 1976; Sociedad Sexológica de Madrid-Fundación Sexpol 1996).

The main exception to this pattern of scarcity in studies on sexuality is the relative wealth of research on prostitution (Andreu Sanz and Vázquez Antón 1989; Cebrián Franco 1977; De Paula Medeiros 2000; Dirección General de la Mujer de la Comunidad de Madrid 1991; Dirección General de la Policía 1986; Draper Miralles 1982; Estébanez Estébanez 1990; Guasch 2000b; Hart 1998; Moral 1980; 
Negre 1988; Pons 1992; Santamaría, Martínez-Toledano, and Espinosa 1988; Sequeiros Tizón, Bruna Quintas, and Gómez 1996). In Spain, the penal code defines as a crime both the promotion of minors' prostitution and forced prostitution of people of any age. However, prostitution itself is not defined as a crime under the law, and therefore it is not illegal. In contrast with the analysis of other areas of social reality, a significant proportion of studies on prostitution has been carried out by male scholars. Most studies analyze prostitutes, but not their pimps or clients. Most research analyzes street prostitution, but not that which takes place in other places such as clubs, saunas, or massage parlors. Scholars have studied female prostitution but hardly that exercised by men. In general, prostitution has been only rarely conceptualized by academic studies as sexual social deviance. Many scholars have interpreted prostitution mainly as a problem of social exclusion related to the underclass and the lower classes, although most (but not all) authors have recognized that prostitutes are an internally heterogeneous group. Up to the 1980s, most Spanish feminists conceived of prostitution as an extreme form of women's exploitation that undermines the status of all women in society (whether prostitutes or not). The long-term goal to be achieved then was the eradication of prostitution. However, since approximately the late 1980s, some feminists have conceptualized prostitutes as sex workers. These feminists have demanded that the state treat prostitutes like other workers, for example, allowing them to contribute to the social security system (Forum de Política Feminista 1991).

Scholarly studies on gay and lesbian sexuality have developed with difficulty and later in Spain than in other Western countries chiefly because of the former hostile political context and the former and current inhospitable academic environments. During the Franco regime, authorities used several pieces of legislation to repress homosexual behavior. For instance, the 1933 Vagrancy and Villainy Act (Ley de vagos y maleantes) was modified in 1954 to include homosexuals. In 1970, this act was again reformed and became the Social Menace and Rehabilitation Act (Ley de peligrosidad y rehabilitación social). Homosexuals were considered individuals dangerous for society, and some of them were confined in special centers where they participated in mandatory therapies to change their sexual orientation. The Social Menace and Rehabilitation Act was reformed only in 1979 (Calvo 2001; De Fluvià 1978b). A gay and lesbian movement emerged during the transition to democracy in one of the legal scenarios most hostile to gays' rights in the Western world. The Front d'Alliberament Gai de Catalunya is considered the first mass gay organization and was formally established in 1975. It was legalized as late as 1980 . The rest of the gay organizations had to wait until 1983 to be legalized (Calvo 2001). After its appearance, the gay movement immediately called the attention of researchers (Calvo 2001; De Fluvià 1978a; Petit 1983, 1996; Vilà 2000).

Part of the Spanish intellectual production on gays and lesbians has a general character and attempts to describe and explain the hostility toward same-sex relations in the Western world and/or in Spain (Fuentes et al. 2001; García Valdés 1981; Guasch 1995, 2000a; Herrero Brasas 1993a, 1993b, 1997a, 1997b). As a result of international influence, an interest in queer theory has been growing since the late 
1990s. Spanish scholars are either popularizing queer theory produced abroad or are trying to contribute to the elaboration of this approach (Aliaga and Cortés 1997; Herrero Brasas 2000; Llamas 1995, 1997, 1998; Llamas and Vidarte 2000). Scholars familiar with the postmodern perspective have started to analyze the representation of male homosexuality in Spanish cinema and literature (Smith 1996, 1998). Other aspects of gay sexuality, such as the gay subculture (Guasch 2000c), are either little studied or are an almost unexplored territory. Another major hole in gay and lesbian studies in Spain is constituted by analyses of the sexual behavior of sexual dissidents, for instance, on polygamy or monogamy within homosexual relationships, bisexuality, sadomasochism, and risky sexual activity in the era of AIDS.

Reading academic literature on same-sex sexuality in Spain, one gets the firm impression that all Spanish people who are sexually interested in people of their own sex happen to be men. Spanish gay studies are mainly written by men and overwhelmingly focused on the experiences of men. A minority of authors add a footnote to their writings acknowledging the existence of lesbians and the possibility that lesbians' experiences and mobilization may differ from those of male homosexuals. Most scholars do not even bother to make such a small gender-sensitive gesture. The lesbian subculture and the lesbian movement have been only rarely analyzed (Llamas and Vila 1997; Viñuales 2000a, 2000b).

\section{MEN}

In Spain, the study of gender and society is still the analysis of women and society. Men and masculinities have scarcely been researched. Anglo-Saxon anthropologists and ethnographers were the first social scientists interested in this topic. During the Francoist period, these scholars undertook studies of rural Spain, mainly in the south of the country (one of the least economically developed parts of Spain). Anthropologists described Spanish masculinity as centered on heterosexual sexuality, rejection of homosexuality, sexist attitudes, and social practices pronouncedly hostile toward women. Men were supposed to actively maintain the honor of their families. This family honor was a multidimensional feature of social life and included the preservation of the virginity of single women, the faithfulness of married women, and the sexual abstinence of widows (Brandes 1991; Gilmore 1987; Pitt-Rivers 1971, 1979). These anthropological studies have been criticized for presenting a unitary Spanish masculinity deducted only from the experiences of rural, heterosexual, middle-aged married men without taking into account other types of men. Anglo-Saxon anthropologists have also been accused of exaggerating the machismo of Spanish men (Hart 1998). Other forms of masculinity, such as those of the Gypsy community, have been less analyzed (San Román Espinosa 1976).

Studies on men with a more sociological focus started to appear in the 1980s, although the majority of them have been produced since the 1990s. Two main 
topics have interested researchers on men (not listed by order of importance). First, scholars have analyzed the reactions of Spanish men to the advancement of women in all areas of social life. These studies have reached opposite conclusions. For some authors, most men conceptualize women's liberation as an unstoppable process and have adapted to this social change (Baigorri 1995). For other social scientists, the responses of men are more diverse. Some (or many) men have received women's advancement with ambivalence or even aversion and have actively tried to resist the improvement of women's lot and the erosion of male privileges (Falcón 1986). Second, scholars have researched the characteristics of male perpetrators of violence against women (Acín Gómez 2000; Beneyto Arrojo 2000; Echeburúa and Fernández-Montalvo 1998; Roig 1999; Serrano Saiz 2000). Most other topics have been little studied, such as the representation of men in advertising (López Varas 1994; Rey 1994) and male clients of female prostitutes (Hart 1998).

In short, the study of men and masculinities is still in an embryonic stage in Spain. This is an area where more research is badly needed.

\section{CONCLUSION}

I have shown that in the past three decades, an impressive body of studies on gender and Spanish society has been developed. However, a caveat is necessary at this point. An article on existing research on any topic might give the reader the impression that the question has been closely investigated and that there are few aspects that need further research. This is definitely not the case with gender and society in Spain, where the gaps in coverage are enormous. As documented throughout this article, there are many dimensions of each issue that have not yet been researched at all. Therefore, if a scholar wants to investigate one of these dimensions, she or he will have to start from scratch and do a lot of fieldwork, which is very time and resource consuming. A related problem is the inadequate dissemination of research already done. No sociological journal on gender exists in Spain. It is often the case that some publications on gender hardly circulate and that it is very difficult to have access to them or even to know that they exist. Therefore, there is a continual danger of replicating studies already undertaken.

To assess the merits of research on gender in Spanish society, it is important to know that the degree of institutionalization of gender studies in Spain is very low. The central organizational unit of the Spanish university system is the department. No gender studies department exists. ${ }^{8}$ This means that all scholars who do research on gender develop their academic careers in departments dedicated to other disciplines (mainly sociology). Generally speaking, such scholars teach courses on sociological topics different from gender. This occurs because the impact of gender knowledge on the Spanish sociology curriculum has been minimal. In contrast with the United States, with very few exceptions, courses on sociology of gender are hardly taught in Spanish universities. The majority of sociology syllabi do not contain sections on gender or readings on gender. Regarding research, if scholars 
specializing in gender want to fit into their departments, they have to publish on areas other than gender. This institutional framework means a triple shift for gender scholars: to teach courses other than on gender, to publish on topics different than gender, and to research gender and society. This institutional framework is a powerful barrier to many scholars interested in gender (Uriarte 1997a). Future sociological analyses on the development of the sociology of gender in Spain will explain how a rich empirical literature on the topic has been built in such a challenging and nonconducive academic scenario.

\section{NOTES}

1. I have analyzed all articles on gender published in the main social science journals in Spain since their first issues appeared. The journals scrutinized are Documentación Social: Revista de Estudios Sociales y de Sociología Aplicada (Social Documentation: Journal of Social Studies and Applied Sociology), Papers: Revista de Sociología (Papers: Journal of Sociology), Política y Sociedad (Politics and Society), Revista Española de Investigaciones Sociológicas (Spanish Journal of Sociological Research), Revista Internacional de Sociología (International Journal of Sociology), Sistema: Revista de Ciencias Sociales (System: Journal of Social Sciences), and Sociología del Trabajo (Sociology of Work). I have also examined books and chapters mainly from the Library of the Women's Institute. This library has approximately 12,000 volumes and is probably the best library on gender in the country.

2. In Spain, most research in the social sciences is done at the university.

3. I have tried to review sociology works, although this has not always been possible since gender is an interdisciplinary field of knowledge.

4. With the exception of studies on education (see below), the analysis of girlhood and female adolescents has hardly been done in Spain (but see Maquieira d'Angelo 1989).

5. The overwhelming majority of Spaniards consider themselves Catholic ( 85 percent in March 2000). Although the number of practicing Catholics is much lower than the number of self-declared Catholics, it is significant: In March 2000, 21 percent of those self-declared Catholics affirmed that they attend religious services (excluding social events such as weddings, first communions, or funerals) almost every Sunday or religious festivity, and about 3 percent do so various days per week (Centro de Investigaciones Sociológicas 2000).

6. In 1960, the female labor force as a percentage of female population from 15 to 64 years of age was 26 percent in Spain, 43 percent in the United States, and 46 percent in the Organization for Economic Cooperation and Development. In 1990, the parallel figures were 41 percent in Spain, 68 percent in the United States, and 59 percent in the Organization for Economic Cooperation and Development (Organization for Economic Cooperation and Development 1992, 39).

7. Since the 1970s, institutions with the explicit purpose of advancing women's rights and status have been established in all Western countries. These institutions are called "women's policy agencies" or "state feminist institutions" in the literature (McBride Stetson and Mazur 1995).

8. Gender research has acquired a certain degree of institutionalization, for instance, with the creation of interdepartmental gender research institutes.

\section{REFERENCES}

Acín Gómez, Gloria. 2000. Estudio policial sobre delitos contra la libertad sexual: Perfil del agresor (Police study on crimes against sexual freedom: Profile of the male aggressor). In Jornadas: La 
violencia de género en la sociedad actual, edited by Direcció General de la Dona de la Generalitat Valenciana. Valencia, Spain: Direcció General de la Dona de la Generalitat Valenciana.

Alberdi, Inés. 1979. Historia y sociología del divorcio en España (History and sociology of divorce in Spain). Madrid, Spain: Centro de Investigaciones Sociológicas.

1995. Informe sobre la situación de la familia en España (Report on the situation of the family in Spain). Madrid, Spain: Ministerio de Asuntos Sociales.

1999. La nueva familia española (The new Spanish family). Madrid, Spain: Taurus.

Alberdi, Inés, and Pilar Escario. 1986. Estudio sociológico sobre las viudas en España (Sociological study on widows in Spain). Madrid, Spain: Ministerio de Trabajo y Seguridad Social.

- 1990. La situación social de las viudas en España: Aspectos cuantitativos (Widows' social situation in Spain: Quantitative aspects). Madrid, Spain: Ministerio de Asuntos Sociales.

Alberdi, Inés, and María A. García de León. 1990. La sociología de la mujer en España (The sociology of women in Spain). In Sociología en España, edited by Salvador Giner and Luis Moreno. Madrid, Spain: Consejo Superior de Investigaciones Científicas and Instituto de Estudios Sociales Avanzados.

Alberdi, Isabel, and Inés Alberdi. 1984. Mujer y educación: Un largo camino hacia la igualdad de oportunidades (Women and education: A long way from equality of opportunity). Revista de Educación e Investigación 275:5-18.

Alcobendas Tirado, María P. 1983. Datos sobre el trabajo de la mujer en España (Data on women's work in Spain). Madrid, Spain: Centro de Investigaciones Sociológicas.

Aliaga, Juan V., and José M. Cortés. 1997. Identidad y diferencia: Sobre la cultura gay en España (Identity and difference: On gay culture in Spain). Barcelona, Spain: Egales.

Almarcha Barbado, Amparo, Benjamín González Rodríguez, and Celia González Jorge. 1994. Cambio y desigualdad en el profesorado universitario (Change and inequality among university professors). Revista Española de Investigaciones Sociológicas 66:117-39.

Álvarez, Lilí, Concepción Borreguero, María Campo Alange, Elena Catena, Consuelo de la Gándara, María Jiménez, Carmen Pérez Seoane, Mary Salas, and Pura Salas. 1970. Mujer y aceleración histórica (Women and social change). Madrid, Spain: Edicusa.

Álvaro Page, Mariano. 1996a. Diferencias en el uso del tiempo, entre varones y mujeres y otros grupos sociales (Differences in time use between men, women, and other social groups). Revista Española de Investigaciones Sociológicas 74:291-326.

1996b. Los usos del tiempo como indicadores de la discriminación entre géneros (Time uses as indicators of gender discrimination). Madrid, Spain: Instituto de la Mujer.

Andreu Sanz, Rosa, and Karmele Vázquez Antón. 1989. Young women prostitutes in Bilbao: A description and an interpretation. In Growing up good: Policing the behavior of girls in Europe, edited by Maureen Cain. London: Sage.

Aranguren, José L. 1973. Erotismo y liberación de la mujer (Eroticism and women's liberation). Barcelona, Spain: Ariel.

Arbiza Berregui, María I. 1978. La madre soltera frente a la sociedad (Nonmarried mothers and society). Papers: Revista de Sociología 9:173-96.

Arenas Fernández, María G. 1996. Triunfantes perdedoras: Investigación sobre la vida de las niñas en la escuela (Triumphant losers: Research on the girls' life at school). Málaga, Spain: Universidad de Málaga and Instituto Andaluz de la Mujer.

Arranz, Fátima. 2000. Algunas notas tecnológicas sobre los Planes de Igualdad de Oportunidades en el marco de las políticas públicas dirigidas a las mujeres: El caso español (Some notes on the gender equality plans: The Spanish case). In Las políticas públicas a favor de las mujeres: De la teoría a la práctica, edited by Fátima Arranz. Madrid, Spain: Instituto de Investigaciones Feministas de la Universidad Complutense de Madrid and Asociación Cultural Al-Mudayna.

Astelarra, Judith. 1990. Participación política de las mujeres (Women's political participation). Madrid, Spain: Centro de Investigaciones Sociológicas.

-1994. Polítiques dels adjuntaments de Catalunya a favor de les dones (Local policies for women in Catalonia). Barcelona, Spain: Institut Català de la Dona. 
Baigorri, Artemio. 1995. El hombre perplejo: Adaptación y cambio de actitudes de los hombres frente al ascenso social de las mujeres (The puzzled man: Men's adaptation and attitude change because of women's social promotion). Badajoz, Spain: Dirección General de la Mujer de la Junta de Andalucía.

Ballarín Domingo, Pilar. 1994. La educación contemporánea de las mujeres (Women's education in contemporary times). In Historia de la educación en la España contemporánea: Diez años de investigación, edited by Jean-Louis Guereña, Julio Ruiz Berrio, and Alejandro Triana Ferrer. Madrid, Spain: Ministerio de Educación y Ciencia.

Benería, Lourdes. 1977. Mujer, economía y patriarcado durante la España franquista (Women, economy, and patriarchy in Franco's Spain). Barcelona, Spain: Anagrama.

Beneyto Arrojo, María J. 2000. Evaluación y tratamiento de los hombres violentos (Assessment and treatment of violent men). In Ponencias presentadas en las jornadas sobre la violencia de género en la sociedad actual, edited by Direcció General de la Dona de la Generalitat de Valencia. Valencia, Spain: Direcció General de la Dona de la Generalitat de Valencia.

Blanco García, Nieves. 2000. El sexismo en los materiales educativos de la ESO (Sexism in secondary school materials). Seville, Spain: Instituto Andaluz de la Mujer.

Bonal, Xavier. 1997. Las actitudes del profesorado ante la coeducación: Propuestas de intervención (Teachers' attitudes toward mixed schooling: Proposals to intervene). Barcelona, Spain: Universitat Autònoma de Barcelona.

- 1998. Canviar l'escola: La coeducació al pati de jocs (Changing schools: Mixed schooling in the schoolyard). Barcelona, Spain: Universitat Autònoma de Barcelona.

Borderías Mondéjar, Cristina. 1986. Evolución de la división sexual del trabajo, Barcelona 1924-1980, aproximación desde una empresa del sector servicios: La Compañía Telefónica Nacional de España (The evolution of sexual division of labor, Barcelona 1924-1980, study of a company in the service sector: The Spanish National Telephone Company). Barcelona, Spain: Universitat de Barcelona.

Borreguero, Concha, Elena Catena, Consuelo de la Gándara, and María Salas. 1986. La mujer española: De la tradición a la modernidad (1960-1980) (Spanish women: From tradition to modernity [19601980]). Madrid, Spain: Tecnos.

Brandes, Stanley. 1991. Metáforas de la masculinidad: Sexo y estatus en el folklore andaluz (Metaphors of masculinity: Sex and status in Andalusian folklore). Madrid, Spain: Taurus.

Bustelo Ruesta, María. 1999. Políticas públicas de igualdad de género en España: Evolución y evaluación (Gender equality policies in Spain: Evolution and evaluation). In Género y ciudadanía: Revisiones desde el ámbito privado, edited by Margarita Ortega, Cristina Sánchez, and Celia Valiente. Madrid, Spain: Universidad Autónoma de Madrid.

Calero Fernández, Sagrario. 1999. Sexismo lingüístico: Análisis y propuestas ante la discriminación sexual en el lenguaje (Linguistic sexism: Analysis and proposals against sexual language discrimination). Madrid, Spain: Narcea.

Calle Fuentes, Mercedes, Carmen González Romero, and Juan A. Núñez Triguero. 1988. Discriminación y acoso sexual a la mujer en el trabajo (Discrimination and sexual harassment against women at work). Madrid, Spain: Fundación Largo Caballero.

Calvo, Kerman. 2001. El movimiento homosexual en la transición a la democracia en España (The homosexual movement in the transition to democracy in Spain). Orientaciones 2:85-109.

Campo Bolado, Rosa E., Elena Espinosa Angulo, María A. García Viejo, Julia M. Hernández Hernández, María J. Morales Bernal, and Aurora Quirós Palacio. 1996. Enseñanzas medias: ¿Educación mixta o coeducación? (Secondary schooling: Mixed or coeducational schooling?). Oviedo, Spain: Principado de Asturias.

Capel Martínez, Rosa M. 1986. El trabajo y la educación de la mujer en España (1900-1930) (Women's work and education in Spain [1900-1930]). 2d ed. Madrid, Spain: Instituto de la Mujer.

Carrasco, Cristina. 1991. El trabajo doméstico y la reproducción social (Domestic work and social reproduction). Madrid, Spain: Instituto de la Mujer. 
Carrasco, Cristina, Anna Alabart, Maribel Mayordomo, and Teresa Montagut. 1997. Mujeres, trabajos y políticas sociales: Una aproximación al caso español (Women, work, and social policy: An approximation to the Spanish case). Madrid, Spain: Instituto de la Mujer.

Carreño, Antonieta, María L. Fabra, Caterina Lloret, Mercè Pallejà, Chei Pastor, and Nuria Pérez de Lara. 1998. La carrera de les professores universitàries (The career of female professors). Barcelona, Spain: Institut Català de la Dona and Institut de Ciències de l'Educació de la Universitat Autònoma de Barcelona.

Casal, J., J. Masjuan, and J. Planas. 1989. Educación e inserción social de las mujeres y los hombres de 25 años (Education and labor force participation of women and men aged twenty-five years). Revista de Educación 290:177-95.

Castaño, Cecilia, Carlos Iglesias, Elena Mañas, and Mario Sánchez-Herrero. 1999. Diferencia o discriminación: La situación de las mujeres españolas en el mercado de trabajo y el impacto de las tecnologías de la información (Difference or discrimination: The situation of Spanish women in the labor market and the impact of information technologies). Madrid, Spain: Consejo Económico y Social.

Castaño, Rosario. 1996. La vida sexual de las mujeres españolas (Spanish women's sexual life). In Salud, dinero y amor: Cómo viven las mujeres españolas de hoy, edited by Cecilia Castaño and Santiago Palacios. Madrid, Spain: Alianza.

Cebrián Franco, J. J. 1977. Prostitución y sociedad (Prostitution and society). Barcelona, Spain: ATE.

Centro de Investigaciones Sociológicas. 2000. Study number 2,387, March. Retrieved 22 May 2000 from http://www.cis.es/baros/mar2387.htm.

Cortada Andreu, Esther. 1988. Escuela mixta y coeducación en Cataluña durante la II República (Mixed school and coeducation in Catalonia during the Second Republic). Madrid, Spain: Instituto de la Mujer.

Cousins, Christine. 1994. A comparison of the labor market position of women in Spain and the UK with reference to the "flexible" labor debate. Work, Employment \& Society 8 (1): 45-67.

- 1995. Women and social policy in Spain: The development of a gendered welfare regime. Journal of European Social Policy 5 (3): 175-97.

De Borja, María. 1970. Carreras y sexos (University studies and sexes). Barcelona, Spain: Terra Nova.

De Fluvià, Armand. 1978a. El movimiento homosexual en el Estado español (The homosexual movement in Spain). In El homosexual ante la sociedad enferma, edited by José R. Enríquez. Barcelona, Spain: Tusquets.

-1978b. La represión legal (Legal repression). In El homosexual ante la sociedad enferma, edited by José R. Enríquez. Barcelona, Spain: Tusquets.

De la Fuente Vázquez, Dolores. 1998. Análisis de la negociación colectiva de la Comunidad Foral de Navarra desde la perspectiva de género (Analysis of collective bargaining in Navarre from a gender perspective). Pamplona, Spain: Instituto Navarro de la Mujer.

De Miguel, Amando. 1975. Sexo, mujer y natalidad en España (Sex, women and birth rates in Spain). Madrid, Spain: Edicusa.

De Miguel, Jesús. 1979. El mito de la inmaculada concepción (The myth of the immaculate conception). Barcelona, Spain: Anagrama.

De Paula Medeiros, Regina. 2000. Fantasía y realidad en la prostitución: SIDA, prácticas sexuales y uso de preservativos (Fantasy and reality around prostitution: AIDS, sexual practices and condom use). Barcelona, Spain: Crónica.

Di Febo, Giuliana. 1979. Resistencia y movimiento de mujeres en España 1936-1976 (Resistance and the women's movement in Spain 1936-1976). Barcelona, Spain: Icaria.

Dirección General de la Mujer de la Comunidad de Madrid. 1991. La prostitución femenina en Madrid (Female prostitution in the city of Madrid). Madrid, Spain: Dirección General de la Mujer de la Comunidad de Madrid.

Dirección General de la Policía. 1986. La prostitución en España (Prostitution in Spain). Madrid, Spain: Dirección General de la Policía. 
Domenech Almendros, Ana. 1994. Mujer y divorcio: De la crisis a la independencia (Woman and divorce: From crisis to independence). Valencia, Spain: Promolibro.

Draper Miralles, Ramón. 1982. Guía de la prostitución femenina en Barcelona (Guide of female prostitution in Barcelona). Barcelona, Spain: Martínez Roca.

Durán, María Á. 1987. De puertas adentro (Indoors). Madrid, Spain: Instituto de la Mujer.

Durán, María Á., and María T. Gallego. 1986. The women's movement in Spain and the new Spanish democracy. In The new women's movement: Feminism and political power in Europe and the USA, edited by Drude Dahlerup. London: Sage.

Echeburúa, Enrique, and Javier Fernández-Montalvo. 1998. Hombres maltratadores (Men who batter). In Manual de violencia familiar, edited by Enrique Echeburúa and Paz del Corral. Madrid, Spain: Siglo XXI.

Escario, Pilar, and Inés Alberdi. 1987. El impacto de las nuevas tecnologías en la formación y el trabajo de las mujeres (The impact of new technologies in the women's training and work). Madrid, Spain: Instituto de la Mujer.

Escario, Pilar, Inés Alberdi, and Ana I. López-Accotto. 1996. Lo personal es político: El movimiento feminista en la transición (The personal is political: The feminist movement during the Spanish transition to democracy). Madrid, Spain: Instituto de la Mujer.

Esping-Andersen, Gosta. 1990. The three worlds of welfare capitalism. Princeton, NJ: Princeton University Press.

Estébanez Estébanez, Pilar. 1990. Prostitution and AIDS in Spain. In AIDS, drugs, and prostitution, edited by Martin Plant. London: Routledge.

Fagoaga, Concha. 1994. Comunicando violencia contra las mujeres (Comunicating violence against women). Estudios sobre el Mensaje Periodístico 1:67-90.

Falcón, Lidia. 1986. El varón español a la búsqueda de su identidad (The Spanish man searching for his identity). Barcelona, Spain: Plaza \& Janés.

Fernández, José M., and Xaiver Aierdi. 1997. Entramado organizativo del movimiento feminista en el País Vasco (Organizational structures of the feminist movement in the Basque Country). Revista Española de Investigaciones Sociológicas 80:183-201.

Fernández Cordón, Juan A., and Constanza Tobío Soler. 1998. Las familias monoparentales en España (One-parent families in Spain). Revista Española de Investigaciones Sociológicas 83:51-85.

1999. Las familias monoparentales en España (One-parent families in Spain). Madrid, Spain: Ministerio de Trabajo y Asuntos Sociales.

Fernández Enguita, Mariano. 1989. La tierra prometida: La contribución de la escuela a la igualdad de la mujer (The promised land: The contribution of school to women's equality). Revista de Educación 290:21-41.

1990. Sísifo en la escuela: Los efectos contradictorios de las reformas del sistema escolar (Sisyphus at school: The contradictory effects of reforms in the school system). Educa 22:12-17.

1991. Hágalo usted mismo: La cualificación del trabajo doméstico, la crisis de su aprendizaje y la responsabilidad de la escuela (Do it yourself: Qualification for domestic work, its learning crisis and the school's responsibility). Madrid, Spain: Ministerio de Educación y Ciencia.

Fernández Méndez de Andrés, Fernando, Marta Casares Bidaroso, Carlos Peralta de Grado, and José M. Rodríguez-Rodríguez. 1987. La actividad laboral de la mujer en relación a la fecundidad (The relationship between female labor force participation and fertility). Madrid, Spain: Instituto de la Mujer.

Fernández Villanueva, Concepción. 1989. La mujer en la universidad española: Docencia, investigación y poder, datos y aspectos cualitativos (Women in the Spanish university: Teaching, research and power-numerical and qualitative data). Revista de Educación 290:161-71.

Finkel Morgenstern, Lucila. 1997. El reparto del trabajo doméstico en la familia: La socialización en las diferencias de género (The division of domestic work within the family: The socialization of gender differences). Madrid, Spain: Confederación Española de Asociaciones de Padres y Madres de Alumnos.

Folguera, Pilar. 1988. El feminismo en España: Dos siglos de historia (Feminism in Spain: Two centuries of history). Madrid, Spain: Fundación Pablo Iglesias. 
Forum de Política Feminista. 1991. Prostitución: Debate y propuestas del movimiento feminista (Prostitution: Debate and proposals from the feminist movement). Madrid, Spain: Forum de Política Feminista.

Fuentes, Pablo, Paco Alcaide, Juan V. Aliaga, Jesús Generelo, Ernesto Farraluque, and Mili Fernández. 2001. En clave gay: Todo lo que deberíamos saber (In gay code: All that we should know). Barcelona, Spain: Egales.

Gaitán, Juan A., and María D. Cáceres. 1995. La mujer en el discurso político (Women in political discourse). Revista Española de Investigaciones Sociológicas 69:125-47.

García, Maribel, Helena Troiano, and Miquel Zaldívar. 1993. El sexismo en los libros de texto: Análisis y propuesta de un sistema de indicadores (Sexism in textbooks: Analysis and proposal of a system of indicators). Madrid, Spain: Instituto de la Mujer.

García de Cortázar, Marisa, and María A. García de León. 1997. Mujeres en minoría: Una investigación sobre las catedráticas de universidad en España (Minority women: Full professors in the Spanish university). Madrid, Spain: Centro de Investigaciones Sociológicas.

García de León, María A. 1991. Las mujeres políticas españolas: Un ensayo sociológico (Female politicians: A sociological essay). Madrid, Spain: Dirección General de la Mujer de la Comunidad de Madrid.

- 1996. Las élites políticas femeninas (Female political elites). In Sociología de las mujeres españolas, edited by María A. García de León, Marisa García de Cortázar, and Félix Ortega. Madrid, Spain: Complutense.

García Escribano, Juan J., and Lola Frutos Balibrea. 1999. Mujeres, hombres y participación política: Buscando las diferencias (Women, men, and political participation: In search of the differences). Revista Española de Investigaciones Sociológicas 86:307-29.

García Ferrando, Manuel. 1977. Mujer y sociedad rural: Un análisis sociológico sobre trabajo e ideología (Women and rural society: A sociological analysis of work and ideology). Madrid, Spain: Cuadernos para el Diálogo.

García Ramón, María D., Josefina Cruz Villalón, Isabel Salamanca Serra, and Montserrat Vilariño Pérez. 1995. Mujer y agricultura en España: Género, trabajo y contexto regional (Women and agriculture in Spain: Gender, work and regional context). Barcelona, Spain: Oikos-Tau.

García Valdés, Alberto. 1981. Historia y presente de la homosexualidad: Análisis crítico de un fenómeno conflictivo (History and present of homosexuality: A critical analysis of a troubled phenomenon). Madrid, Spain: Akal.

Garreta, Nuria, and Pilar Careaga. 1987. Modelos masculino y femenino en los textos de EGB (Female and male images in elementary school textbooks). Madrid, Spain: Instituto de la Mujer.

Gil, Juana M. 1996. Las políticas de igualdad en España (Gender equality policies in Spain). Granada, Spain: Universidad de Granada.

Gilmore, David D. 1987. Aggression and community: Paradoxes of Andalusian culture. New Haven, CT: Yale University Press.

González, Celia, and Amparo Almarcha. 1993. Equal treatment of women. In Spain and EC membership evaluated, edited by Amparo Almarcha. London: Pinter.

González Duro, Enrique. 1999. Mujeres separadas (Divorced women). Madrid, Spain: Talasa.

Granados Vaquero, Elena. 1999. El Instituto Andaluz de la Mujer (The Andalusian Women's Institute). In Género y ciudadanía: Revisiones desde el ámbito privado, edited by Margarita Ortega, Cristina Sánchez, and Celia Valiente. Madrid, Spain: Universidad Autónoma de Madrid.

Gregorio Gil, Carmen. 1998. Migración femenina: Su impacto en las relaciones de género (Female migration: Its impact on gender relations). Madrid, Spain: Narcea.

Grup de Feminisme de l'Escola de Sociologia de Barcelona. 1978. Forman part del moviment feminista de Barcelona: Les vocalies (Being part of the feminist movement in Barcelona). Papers: Revista de Sociología 9:197-216.

Guasch, Òscar. 1993. Para una sociología de la sexualidad (On sociology of sexuality). Revista Española de Investigaciones Sociológicas 64:105-21.

— 1995. La sociedad rosa (The pink society). $2 \mathrm{~d}$ ed. Barcelona, Spain: Anagrama. 
2000a. La crisis de la heterosexualidad (The crisis of heterosexuality). Barcelona, Spain: Laertes.

- 2000b. La prostitución masculina homosexual: Aproximación general (Homosexual male prostitution: A general approach). Orientaciones 1:149-57.

$.2000 \mathrm{c}$. Subcultura gai i lèsbica (The gay and lesbian subculture). In Homosexualitat al'inicidel segle XXI, edited by Antoni Mirabet i Mullol. Barcelona, Spain: Claret.

Guillén, Ana M. 1997. Regímenes de bienestar y roles familiares: Un análisis del caso español (Welfare regimes and family roles: An analysis of the Spanish case). Papers: Revista de Sociología 53:45-63.

Gutiérrez, Carmen, and Inma Pastor. 1996. Las mujeres en la Administración Pública catalana (Women in the Catalan public administration). In Sociología de las relaciones de género, edited by Cristina Brullet and Pilar Carrasquer. Madrid, Spain: Instituto de la Mujer.

Hart, Angie. 1998. Buying and selling power: Anthropological reflections on prostitution in Spain. Boulder, CO: Westview.

Hernández Rodríguez, Gerardo. 1996. Situación socio-económica das mulleres separadas en Galicia (The socioeconomic situation of divorced women in Galicia). Santiago de Compostela, Spain: Xunta de Galicia.

Herrero Brasas, Juan A. 1993a. La sociedad gay: Una invisible minoría. 1. Ciencia, prejuicio social y homosexualidad (The gay society: An invisible minority. 1. Science, social prejudice, and homosexuality). Claves de Razón Práctica 36:20-33.

- 1993b. La sociedad gay: Una invisible minoría. 2. Familia, sistema educativo, religión y fuerzas armadas (The gay society: An invisible minority. 2. Family, education system, religion and the armed forces). Claves de Razón Práctica 37:26-42.

-1997a. El matrimonio gay: Un reto al estado heterosexual (The gay marriage: A challenge to the heterosexual state). Claves de Razón Práctica 73:42-54.

-1997b. La guerra de los números (The war of numbers). In Conciencia de un singular deseo: Estudios lesbianos y gays en el estado español, edited by Xosé M. Buxán Bran. Barcelona, Spain: Laertes.

-2000. Teoría “queer": Activismo, "outing” y cuartos oscuros (Queer theory: Activism, outing and dark rooms). Claves de Razón Práctica 106:15-25.

Iglesias de Ussel, Julio. 1983. La sociología de la sexualidad en España (The sociology of sexuality in Spain). Revista Española de Investigaciones Sociológicas 21:103-33.

1988. Las familias monoparentales (One-parent families). Madrid, Spain: Instituto de la Mujer. Iglesias de Ussel, Julio, and Lluís Flaquer. 1993. Familia y análisis sociológico: El caso de España (The family and sociological analysis: The case of Spain). Revista Española de Investigaciones Sociológicas 61:57-76.

IMOP Encuestas. 1999. La situación de la mujer en la toma de decisiones (Women in decision-making positions). Madrid, Spain: Instituto de la Mujer.

INNER. 1988. Los hombres españoles (Spanish men). Madrid, Spain: Instituto de la Mujer.

Instituto de la Mujer. 1987a. El trabajo de las mujeres (Women's work). Madrid, Spain: Instituto de la Mujer.

- 1987b. La investigación en España sobre mujer y educación (Research on women and education in Spain). Madrid, Spain: Instituto de la Mujer.

-1989. Mujer e igualdad de oportunidades en el empleo (Women and equality of opportunities in employment). Madrid, Spain: Instituto de la Mujer.

- 1993a. Estudio sociológico sobre la carrera administrativa de las mujeres (Sociological study on women's career in public administration). Madrid, Spain: Instituto de la Mujer.

- 1993b. Las mujeres en la Administración del Estado (Women in public administration). Madrid, Spain: Instituto de la Mujer.

1997. La igualdad de oportunidades en el ámbito laboral (Equality of opportunities in the labor market). Madrid, Spain: Instituto de la Mujer.

Instituto IDES. 1988. Las españolas ante la política (Spanish women and politics). Madrid, Spain: Instituto de la Mujer. 
Interparliamentary Union. 2001. Women in national Parliaments: Situation as of 1 July 2001. Retrieved 28 July 2001 from http://www.ipu.org/wmn-e/classif.htm.

Izarra, Miren, and Asunción López Carretero. 1999. El femení com a mirall de l'escola (The feminine as a reflection of schooling). Barcelona, Spain: Institut d'Educació.

Izquierdo, Jesusa, Olga del Río, and Agustín Rodríguez. 1988. La desigualdad de las mujeres en el uso del tiempo (Women's inequality in the use of time). Madrid, Spain: Instituto de la Mujer.

Kaplan, Gisela. 1992. Contemporary Western European feminism. London: UCL Press and Allen \& Unwin.

Lázaro, Nieves, and Rosario Sánchez. 1993. Las mujeres y el mercado de trabajo en España: De la transición a la democracia (Women and the labor market in Spain since the transition to democracy). In Las mujeres y la recesión, edited by Jill Rubery. Madrid, Spain: Ministerio de Trabajo y Seguridad Social.

Liceras, Dolores, and Soledad Murillo de la Vega. 1992. La mujer asalariada ante la negociación colectiva (Waged female workers and collective bargaining). Madrid, Spain: Fundación Primero de Mayo.

Llamas, Ricardo. 1995. Construyendo sidentidades: Estudios desde el corazón de una pandemia (Building AIDS identities: Studies from the heart of a pandemic). Madrid, Spain: Siglo XXI.

- 1997. Miss media: Una lectura perversa de la comunicación de masas (Miss media: A perverse look at mass communication). Barcelona, Spain: La Tempestad.

1998. Teoría torcida: Prejuicios y discursos en torno a la homosexualidad (Queer theory: Prejudices and discourses on homosexuality). Madrid, Spain: Siglo XXI.

Llamas, Ricardo, and Paco Vidarte. 2000. Homografías (Homographies). Madrid, Spain: Espasa-Calpe.

Llamas, Ricardo, and Fefa Vila. 1997. Spain: Passion for life: Una historia del movimiento de lesbianas y gays en el Estado Español (Passion for life: A history of the lesbian and gay movement in Spain). In Conciencia de un singular deseo: Estudios lesbianos y gays en el Estado español, edited by Xosé M. Buxán Bran. Barcelona, Spain: Laertes.

López, Félix. 1990. La sexualidad de los universitarios: Un estudio comparativo (1977-1987) (The sexuality of university students: A comparative study [1977-1987]). Revista de Sexología 42:1-20.

López Varas, María L. 1994. El hombre y la cosmética: Del modelo de consumo tradicional al modelo de consumo moderno (Men and cosmetics: From the traditional to the modern consumer model). Política y Sociedad 16:201-9.

Madruga, Isabel, and Rosalía Mota. 2000. Las condiciones de vida de los hogares pobres encabezados por una mujer: Pobreza y género (Living conditions of households headed by a woman: Poverty and gender). Madrid, Spain: Fundación Foessa and Cáritas.

Maquieira d'Angelo, Virginia. 1989. Boys, girls and the discourse of identity: Growing up in Madrid. In Growing up good: Policing the behavior of girls in Europe, edited by Maureen Cain. London: Sage.

Maquieira d'Angelo, Virginia, Carmen Gregorio Gil, and Elena Gutiérrez Lima. 2000. Políticas públicas, género e inmigración (Public policies, gender and immigration). In También somos ciudadanas, edited by Pilar Pérez Cantó. Madrid, Spain: Universidad Autónoma de Madrid.

Maquieira d'Angelo, Virginia, and Cristina Sánchez Muñoz. 1990. Violencia y sociedad patriarcal (Violence and patriarchal society). Madrid, Spain: Pablo Iglesias.

Martín Serrano, Esperanza, and Manuel Martín Serrano. 1999. Las violencias cotidianas cuando las víctimas son las mujeres (Everyday violence when victims are women). Madrid, Spain: Instituto de la Mujer.

Martín Urriza, Carlos, and Luis Zarapuz Puertas. 2000. Empleo y discriminación salarial: Un análisis desde la perspectiva de género (Employment and wage discrimination: An analysis from the gender perspective). Madrid, Spain: Comisiones Obreras.

Martínez, Eva, and Arantxa Elizondo. 1997. Women in politics: Are they really concerned about equality? An essay on the Basque political system. European Journal of Women's Studies 4:451-72.

McBride Stetson, Dorothy, and Amy G. Mazur. 1995. Comparative state feminism. Thousand Oaks, CA: Sage. 
Meil Landwerlin, Gerardo. 1998. La sociología de la familia en España, 1978/1998 (The sociology of the family in Spain, 1978/1999). Revista Española de Investigaciones Sociológicas 83:179-215.

Mendizábal, Garbiñe, and Esther Ortiz. 1996. Del discurso de la igualdad a los planes de igualdad de oportunidades entre hombres y mujeres: Análisis de la Comunidad Autónoma Vasca (From the discourse on gender equality to gender equality plans: Analysis of the Basque country). In Sociología de las relaciones de género, edited by Cristina Brullet and Pilar Carrasquer. Madrid, Spain: Instituto de la Mujer.

Ministerio del Interior and Instituto de la Mujer. 1991. Violencia contra la mujer (Violence against women). Madrid, Spain: Ministerio del Interior.

Molina Petit, Cristina. 1996. La igualdad no resuelta: Mujer y participación política, un estudio en Gran Canaria (Nonsolved equality: Women and political participation, a study on Gran Canaria). Las Palmas de Gran Canaria, Spain: Instituto Canario de la Mujer.

Moltó Carbonell, María L. 1993. Las mujeres en el proceso de modernización de la economía española (Women in the modernization process of the Spanish economy). In Las mujeres y la recesión, edited by Jill Rubery. Madrid, Spain: Ministerio de Trabajo y Seguridad Social.

Moral, Enrique. 1980. Nuestra prostitución (Our prostitution). Lugo, Spain: Alvarello.

Morales, Laura. 1999. Participación política en España: Un análisis de las diferencias de género (Political participation in Spain: An analysis of gender differences). In Género y ciudadanía: Revisiones desde el ámbito privado, edited by Margarita Ortega, Cristina Sánchez, and Celia Valiente. Madrid, Spain: Universidad Autónoma de Madrid.

Moreno, Almudena. 2000. Las familias monoparentales en España (One-parent families in Spain). Revista Internacional de Sociología 26:39-63.

Moreno, Montserrat. 1992. Del silencio a la palabra: Coeducación y reforma educativa (From silence to words: Mixed schooling and education reform). Madrid, Spain: Instituto de la Mujer.

Moreno Raymundo, Gloria, José M. Rodríguez Rodríguez, and Joaquín Vera Grijalba. 1996. La participación laboral femenina y la discriminación salarial en España (1990-1991) (Female labor force participation and wage discrimination in Spain [1990-1991]). Madrid, Spain: Consejo Económico y Social.

Negre, Pere. 1988. La prostitución popular: Relatos de vida (Low-class prostitution: Life stories). Barcelona, Spain: Fundació Caixa de Pensions.

Oleaga, Ricardo. 1990. El ama de casa, hoy (Homemakers today). Elorrio, Bizkaia, Spain: Eroski.

Organization for Economic Cooperation and Development. 1992. Historical statistics. Paris: Organization for Economic Cooperation and Development.

Ortiz Corulla, Carmen. 1987. La participación política de las mujeres en la democracia (1979-1986) (Women's political participation in the democracy [1979-1986]). Madrid, Spain: Instituto de la Mujer.

Osborne, Raquel. 2001. La violencia contra las mujeres (Violence against women). Madrid, Spain: Universidad Nacional de Educación a Distancia.

Peinado López, María A. 1988. Discriminación de la mujer en el mercado de trabajo español (Gender discrimination in the Spanish labor market). Madrid, Spain: Ministerio de Trabajo y Seguridad Social.

Pernas, Begoña, M. Román, J. Olza, and M. Naredo. 2000. La dignidad quebrada: Las raíces del acoso sexual en el trabajo (Snapped dignity: The roots of sexual harassment at work). Madrid, Spain: Los Libros de la Catarata.

Petit, Jordi. 1983. El movimiento gai y la cuestión homosexual en España (The gay movement and the homosexual question in Spain). A Priori 6-7:57-66.

- 1996. Gays y lesbianas: La experiencia de la coordinadora gay-lesbiana (Gays and lesbians: The experience of the gay-lesbian coordinator). In Diez palabras clave sobre movimientos sociales, edited by José M. Mardones. Estella, Pamplona, Spain: Verbo Divino.

Pineda, Empar. 1995. Algunas reflexiones sobre el estado actual del feminismo en España (Thoughts on the current state of feminism in Spain). Género y Sociedad 3:95-116.

Pitt-Rivers, Julian. 1971. The people of the sierra. 2d ed. Chicago: Chicago University Press. 
1979. Antropología del honor o política de los sexos: Ensayos de antropología mediterránea (Anthropology of honor or politics of the sexes: Essays of Mediterranean anthropology). Barcelona, Spain: Crítica.

Pons, Ignasi. 1992. Condiciones de vida de las prostitutas en Asturias (Living conditions of prostitutes in Asturias). Oviedo, Spain: Servicio de Publicaciones del Principado de Asturias.

Puleo, Alicia H. 1994. Conceptualizaciones de la sexualidad e identidad femenina (Conceptulizations of female sexuality and identity). Madrid, Spain: Dirección General de la Mujer de la Comunidad de Madrid and Instituto de Investigaciones Feministas de la Universidad Complutense de Madrid.

1996. Feminismo y política en España (Feminism and politics in Spain). Leviatán 63:49-62.

Ramos Palomo, María D. 1998. La medida del mundo: Género y usos del tiempo en Andalucía (The measure of the world: Gender and time use in Andalusia). Seville, Spain: Instituto Andaluz de la Mujer.

Ramos Torres, R. 1990. Cronos dividido (Divided time). Madrid, Spain: Instituto de la Mujer.

Rey, Juan. 1994. El hombre fingido: La representación de la masculinidad en el discurso publicitario (The faked man: The representation of masculinity in the advertising discourse). Madrid, Spain: Fundamentos.

Rodríguez, Luis, Francisco J. Álvarez, and Pilar Gómez. 1988. La justicia ante la libertad sexual de las mujeres (The justice system and women's sexual freedom). Madrid, Spain: Instituto de la Mujer.

Roig, Encarnación. 1994. La libertad sexual violada: Las agresiones sexuales, sus víctimas y su entorno (Violated sexual freedom: Sexual aggression, its victims, and its environment). Madrid, Spain: Dirección General de la Mujer de la Comunidad de Madrid.

- 1999. Estudio sociológico sobre los reclusos por delitos contra la libertad sexual (Sociological study on male inmates condemned of crimes against sexual freedom). Madrid, Spain: Dirección General de la Mujer de la Comunidad de Madrid.

Romero López, Marcial. 1987. La empresaria española (Spanish female employers). Madrid, Spain: Instituto de la Mujer.

- 1990. La actividad empresarial femenina en España (Female employers in Spain). Madrid, Spain: Instituto de la Mujer.

Rubí Pato, María D., and Begoña Núñez González. 1994. Malos tratos a mujeres en Valladolid (Domestic violence against women in Valladolid). Valladolid, Spain: Ayuntamiento de Valladolid.

Ruesga, Santos M. 1991. Las otras trabajadoras: Un análisis de la participación femenina no registrada en la actividad económica (The other female workers: An analysis of the nonregistered female economic participation). Revista de Economía y Sociología del Trabajo 13-14:114-28.

Sáez Lara, Carmen. 1994. Mujeres y mercado de trabajo: Las discriminaciones directas e indirectas (Women and the labor market: Direct and indirect discrimination). Madrid, Spain: Consejo Económico y Social.

Salas, María. 1996. Una mirada sobre los sucesivos feminismos (A look at consecutive feminisms). Documentación Social: Revista de Estudios Sociales y de Sociología Aplicada 105:13-32.

Sallé, María Á., and José I. Casas. 1987. Efectos de la crisis económica sobre el trabajo de las mujeres (Effects of the economic crisis on women's work). Madrid, Spain: Instituto de la Mujer.

Sampedro, María R. 1992. Administración local y políticas de igualdad de la mujer (Local administration and women's policies). Madrid, Spain: Federación Española de Municipios y Provincias.

Sanchís, Enric. 1984. El trabajo a domicilio en el País Valenciano (Working at home in the Valencian country). Madrid, Spain: Instituto de la Mujer.

San Román, Sonsoles. 1998. Las primeras maestras: Los orígenes del proceso de feminización docente en España (The first female teachers: The origins of the feminization process of the teaching profession in Spain). Barcelona, Spain: Ariel.

San Román Espinosa, Teresa. 1976. El buen nombre del gitano (The good name of the Gypsy man). In Temas de antropología española, edited by Carmelo Lisón Tolosana. Madrid, Spain: Akal.

Santamaría, Ana, Balti Martínez-Toledano, and María Espinosa. 1988. La prostitución de las mujeres (Female prostitution). Madrid, Spain: Instituto de la Mujer. 
Sanz Rueda, Carmela. 1995. Invisibilidad y presencia: Seminario internacional "género y trayectoria del profesorado femenino" (Invisibility and presence: International seminar on gender and university professors' career). Madrid, Spain: Dirección General de la Mujer de la Comunidad de Madrid and Instituto de Investigaciones Feministas de la Universidad Complutense de Madrid.

Scanlon, Geraldine M. 1976. La polémica feminista en la España contemporánea (1868-1974) (The feminist polemic in contemporary Spain [1868-1974]). Madrid, Spain: Siglo XXI.

Sensat, Núria, and Reyes Varela. 1998. Las políticas dirigidas a las mujeres: La acción pública para la igualdad de los sexos (Public policies for women: Public actions to enhance sex equality). In Políticas públicas en España, edited by Joan Subirats and Ricard Gomá. Barcelona, Spain: Ariel.

Sequeiros Tizón, José L., Cristina Bruna Quintas, and Concha Gómez. 1996. Estudio sobre a prostitución no sur de Galicia (Study on prostitution in the south of Galicia). Santiago de Compostela, Spain: Xunta de Galicia.

Serrano Saiz, Jesús. 2000. Informe sobre el perfil psicosocial de agresores de violencia doméstica en prisión (Report of the psychosocial profile of inmates charged with a domestic violence). In Ponencias de las jornadas sobre la violencia de género en la sociedad actual, edited by Direcció General de la Dona de la Conselleria de Benestar Social de la Generalitat Valenciana. Valencia, Spain: Direcció General de la Dona de la Conselleria de Benestar Social de la Generalitat Valenciana.

Serrano Vicéns, Ramón. 1976. La sexualidad femenina: Una investigación estadística (Female sexuality: A statistical study). Madrid, Spain: Júcar.

Servicio Galego de Promoción da Igualdade do Home a da Muller. 1992. Agresións sexuais e violencia doméstica contra as mulleres en Galicia: Período 1988-1992 (Sexual attacks and domestic violence against women in Galicia: 1988-1992). Santiago de Compostela, Spain: Servicio Galego de Promoción da Igualdade do Home a da Muller.

Smith, Paul J. 1996. Cinema, literature and sexuality in Spain and Cuba, 1983-93. London: Verso.

1998. Las leyes del deseo: La homosexualidad en la literatura y el cine español, 1960-1990

(The laws of desire: Homosexuality in the Spanish literature and cinema, 1960-1990). Barcelona, Spain: La Tempestad.

Sociedad Sexológica de Madrid-Fundación Sexpol. 1996. Informe Sexpol: El comportamiento sexual de los españoles y las españolas (Sexpol report: Spaniards' sexual behavior). Familias-UNAF: Cuadernos de las Familias Democráticas 17-18.

Subirats, Marina, and Cristina Brullet. 1988. Rosa y azul: La transmisión de los géneros en la escuela mixta (Pink and blue: The transmission of sex roles in mixed schools). Madrid, Spain: Instituto de la Mujer.

Sundman, Kerstin. 1999. Between the home and the institutions: The feminist movement in Madrid, Spain. Gothenburg, Sweden: Acta Universitatis Gothoburgensis.

Threlfall, Monica. 1979. El socialismo y el electorado femenino (Socialism and the female electorate). Sistema: Revista de Ciencias Sociales 32:19-33.

. 1985. The women's movement in Spain. New Left Review 151:44-73.

1996. Feminist politics and social change in Spain. In Feminist politics and social transformation in the North, edited by Monica Threlfall. London: Verso.

1998. State feminism or party feminism? Feminist politics and the Spanish Institute of Women. European Journal of Women's Studies 5 (1): 69-93.

Tobío Soler, Constanza. 1999. Solidaridad y cambio entre generaciones de mujeres (Solidarity and change among generations of women). In Género y ciudadanía: Revisiones desde el ámbito privado, edited by Margarita Ortega, Cristina Sánchez, and Celia Valiente. Madrid, Spain: Universidad Autónoma de Madrid.

Tobío Soler, Constanza, and Juan A. Fernández Cordón. 1999. Monoparentalidad, trabajo y familia (One-parenthood, work, and family). Revista Internacional de Sociología 22:67-97.

Torns, Teresa, Vicent Borràs, and Alfonso Romero. 1999. El acoso sexual en el mundo laboral: Un indicador patriarcal (Sexual harassment at work: A patriarchal indicator). Sociología del Trabajo 36:57-77. 
Uriarte, Edurne. 1997a. Estudios de mujeres y política en España (Studies on women and politics in Spain). In Mujeres en política: Análisis y práctica, edited by Edurne Uriarte and Arantxa Elizondo. Barcelona, Spain: Ariel.

1997b. Las mujeres en las élites políticas (Women in political elites). In Mujeres en política: análisis y práctica, edited by Edurne Uriarte and Arantxa Elizondo. Barcelona, Spain: Ariel.

1997c. Pautas de cultura política y participación en España (Patterns of political culture and participation in Spain). In Mujeres en política: Análisis y práctica, edited by Edurne Uriarte and Arantxa Elizondo. Barcelona, Spain: Ariel.

1999. El acceso de las mujeres a las élites políticas: El caso español (Women's access to political elites: The Spanish case). In Género y ciudadanía: Revisiones desde el ámbito privado, edited by Margarita Ortega, Cristina Sánchez, and Celia Valiente. Madrid, Spain: Universidad Autónoma de Madrid.

Uriarte, Edurne, and Cristina Ruiz. 1999. Mujeres y hombres en las élites políticas españolas: ¿Diferencias o similitudes? (Women and men in the Spanish political elite: Differences or similarities?). Revista Española de Investigaciones Sociológicas 88:207-32.

Valenzuela Ratia, Diego. 1979. El sector doméstico español 1964-1976 (The Spanish domestic sector 1964-1976). Madrid, Spain: Ministerio de Cultura.

Valiente, Celia. 1995a. Children first: Central government child care policies in post-authoritarian Spain (1975-1994). In Childhood and parenthood: Proceedings of ISA committee for family research conference on children and families, 1995, edited by Julia Brannen and Margaret O'Brien. London: Institute of Education/University of London.

- 1995b. The power of persuasion: The Instituto de la Mujer in Spain. In Comparative state feminism, edited by Dorothy McBride Stetson and A. Mazur. Thousand Oaks, CA: Sage.

- 1996. Partial achievements of central-state public policies against violence against women in post-authoritarian Spain (1975-1995). In Women in a violent world: Feminist analyses and resistance across "Europe," edited by Chris Corrin. Edinburgh, Scotland: Edinburgh University Press.

1997a. Gender, segmented labour markets, continental welfare states and equal employment policies: The case of Spain. In Work-Quo vadis? Re-thinking the question of work, edited by Jan Holmer and Jan Ch. Karlsson. Aldershot, UK: Ashgate.

1997b. Políticas de género en perspectiva comparada: La mujer trabajadora en Italia y España (1900-1996) (Gender-equality public policy in comparative perspective: Working women in Italy and Spain [1900-1996]). Madrid, Spain: Universidad Autónoma de Madrid.

1997c. State feminism and gender equality policies: The case of Spain (1983-95). In Sex equality policy in Western Europe, edited by Frances Gardiner. London: Routledge.

. 1998. Sexual harassment in the workplace: Equality policies in post-authoritarian Spain. In The politics of sexuality, edited by Terrell Carver and Véronique Mottier. London: Routledge.

- 1998-1999. Feminismo de Estado en los ayuntamientos de la Comunidad Autónoma de Madrid (State feminism at the local level in the Madrid region). Gestión y Análisis de Políticas Públicas 1314:181-97.

- 2001a. A closed subsystem and distant feminist demands block women-friendly outcomes in Spain. In Making democracies work for women: State feminism, women's movements, and job training policy, edited by Amy G. Mazur. New York: Routledge.

- 2001b. Gendering abortion debates: State feminism in Spain. In Abortion politics, women's movements, and the democratic state, edited by Dorothy McBride Stetson. New York: Oxford University Press.

— 2001c. Movimientos sociales y estados: La movilización feminista en España desde los años sesenta (Social movements and states: Feminist mobilization in Spain since the 1960s). Sistema: Revista de Ciencias Sociales 161:31-58.

Vilà, Enric. 2000. Moviment gai i lèsbic (The gay and lesbian movement). In Homosexualitat a l'inici del segle XXI, edited by Antoni Mirabet i Mullol. Barcelona, Spain: Claret.

Viñuales, Olga. 2000a. Identidades lésbicas: Discursos y prácticas (Lesbian identities: Discourses and practices). Barcelona, Spain: Bellaterra. 
2000b. Identitat i diversitat lèsbiques (Lesbian identities and diversity). In Homosexualitat a l'inici del segle XXI, edited by Antoni Mirabet i Mullol. Barcelona, Spain: Claret.

Younis, José A. 1999. Violencia contra las mujeres y transformación social (Violence against women and social transformation). Las Palmas de Gran Canaria, Spain: Instituto Psicosocial Manuel Alemán Álamo.

Celia Valiente is a visiting professor (profesora visitante) in the Department of Political Science and Sociology at Universidad Carlos III de Madrid, Spain. Her research deals with public policies and social movements in Spain with the perspective of gender. 